\title{
Upaya Memperkuat Desa: Suatu Implementasi Kebijakan Pengangkatan Tenaga Kontrak Daerah Di Kabupaten Halmahera Utara
}

\author{
Simson Tondo ${ }^{1, *}$, Bonny Datty ${ }^{2}$ \\ ${ }^{1}$ Universitas Halmahera, Maluku Utara, Indonesia \\ ${ }^{2}$ Universitas Halmahera, Maluku Utara, Indonesia \\ 1 simson.tondo@gmail.com* \\ * corresponding author
}

\section{ARTICLE INFO}

\section{Article history}

Received 2019-11-28

Revised 2019-12-11

Accepted 2019-12-18

\section{Keywords}

Policy Implementation,

Strengthening Villages,

Regional Contract Workers.

\begin{abstract}
$A B S T R A C T$
The effort to strengthen the village is the constitutional mandate contained in Law Number 6 of 2014 concerning Villages. the law is considered to place the village government as the subject of development in the village, has broad autonomy, and has broad authority in regulating governance in accordance with the potential of each village. On the other hand, there are concerns from the village government because they do not have the ability to carry out the village law mandate. Responding to village worries in North Halmahera, a North Halmahera Regent Decree was born numbered 814.1 / 2018 concerning Appointment of Regional Contract Workers with Work Agreements in Villages in North Halmahera Regency. This study aims to analyze the implementation of the policy for the appointment of regional contract workers in an effort to strengthen villages in North Halmahera Regency. Furthermore, this study uses qualitative research methods. Because of this the unit of analysis of this research is the village government of the Central Tobelo sub-district and the results of this study indicate that the Regional Government Policy of the North Halmahera Regency in the appointment of regional contract workers did not run smoothly in accordance with the program's objectives, due to lack of communication or direct socialization to the village government or community. Most of the contract workers assigned in the villages cannot carry out their main tasks, because of their limited capacity and because they are not given assignments by the local village government. As for funding this program, there is no problem, all regional contract workers are paid above the district minimum wage standard. In the implementation of regional contract personnel recruitment has been carried out openly and transparently. Furthermore, there is no good collaboration between the Regional Personnel Agency and Apparatus Resources with the Community and Village Empowerment Agency in coaching and training so that contract workers cannot carry out their duties properly.
\end{abstract}

\section{PENDAHULUAN}

Memperkuat desa adalah amanat konstitusi yang termuat dalam Undang-Undang Nomor 6 Tahun 2014 Tentang Desa. [1] Seluruh pemerintah desa di Indonesia menyambut baik berlakunya undang-undang desa tersebut, oleh karena menempatkan desa sebagai subjek pembangunan, dimana desa mempunyai kewenangan mengatur dan mengurus pemerintahannya sendiri. Keistimewaan desa misalnya, Pasal 1 ayat 12 UU Nomor 6 Tahun 2014 yang menyatakan bahwa desa merancang kegiatan dan kebijakannya sesuai dengan kebutuhan masyarakat di desa.

Namun pada sisi lain, muncul kekuatiran dari pemerintah desa dikarenakan mereka tidak memiliki kemampuan untuk menjalankan mandat undang-undang desa tersebut. Merespon kekuatiran desa di Halmahera Utara lahirlah Surat Keputusan Bupati Halmahera Utara bernomor 814.1/2018 Tentang Pengangkatan Tenaga Kontrak Daerah dengan Perjanjian Kerja di Desa Dalam Wilayah Kabupaten Halmahera Utara. [2] Tenaga kontrak tersebut ditempatkan di seluruh desa dan pembagiannya tiap desa mendapatkan 2 sampai 3 orang dengan besik ilmu yang berbeda.

Selanjutnya, tenaga kontrak diberi tugas yakni: Memfasilitasi penetapan dan pengelolaan kewenangan lokal berskala desa, Memfasilitasi desa dalam hal kepemimpinan desa, demokratisasi, kaderisasi, lembaga kemasyarakatan desa, ketahanan masyarakat desa, perencanaan, pelaksanaan, evaluasi dan pengawasan pembangunan, pembentukan dan pengembangan BUMDesa, kerjasama antar desa, 
kerjasama desa dengan pihak ketiga, dan melaksanakan tugas-tugas SKPD di desa. (Nomor: 814.1/2018 pasal 6 Surat Perjanjian Kerja).

\section{Permasalahan}

Sejumlah tugas pokok dan fungsi tenaga kontrak di atas belum terlaksananya dengan baik, ini nampak dari keterangan yang disampaikan oleh para kepala desa salah satunya kepala desa Pitu, yang mengatakan bahwa 'awalnya kami sangat senang dengan penempatan tenaga kontrak di desa, namun ternyata kami tidak terbantu dengan kehadiran para tenaga kontrak tersebut, karena semua pekerjaan dikerjakan oleh pemerintah desa. Keluhan juga muncul dari masyarakat setempat bahwa mereka tidak melihat para tenaga kontrak daerah berkantor di kantor desa. Selanjutnya, keterangan permasalahan juga disampaikan oleh para tenaga kontrak. Nino tenaga kontrak di desa WKO misalnya, mengatakan bahwa 'kalau dilihat tupoksi pekerjaan kami sangat banyak. Namun, disamping kurangnya pekerjaan di desa, kami juga kurang dilibatkan dalam aktivitas dan pekerjaan di pemerintah desa'.

Permasalahan di atas menunjukan bahwa pelaksanaan kebijakan pengangkatan tenaga kontrak daerah di kabupaten Halmahera Utara dalam upaya memperkuat desa tidak berjalan dengan baik. Karena itu, penelitian ini bertujuan 'Menganalisis implementasi kebijakan pengangkatan tenaga kontrak daerah dalam upaya memperkuat desa di Kabupaten Halmahera Utara'. Penelitian ini menjadi penting karena belum ada yang meneliti tentang pengangkatan tenaga kontrak daerah di Kabupaten Halmahera Utara, selanjutnya penelitian ini sesuai dengan rencana strategis Universitas Halmahera dan bagaimana memperkuat desa untuk menjalankan tugas dan fungsi pemerintahan desa sebagai garda terdepan dalam melayani masyarakat.

\section{TINJAUAN PUSTAKA}

\section{Kebijakan Publik}

Menurut Robert Eyestone Untuk melihat kebijakan publik pertama-tama perlu melihat hubungan antara pemerintah dan lingkungannya dalam arti setiap kebijakan harus melihat kebutuhan masyarakatnya. [3] Selanjutnya James E. Anderson mengatakan bahwa kebijakan publik adalah segala bentuk aturan yang dinyatakan dan ditetapkan oleh pemerintah. [4]

Deddy Mulyady mengatakan bahwa kebijakan adalah bagaimana Pemerintah mempunyai kewenangan menyelenggarakan tugas negara dan pembangunan dalam bentuk suatu kebijakan untuk mencapai tujuan negara. [5] Sedangkan Menurut William N. Dunn kebijakan publik adalah Suatau rangkaian kegiatan pemerintahan berupa pertahanan keamanan, penyediaan energi, menjamin kesehatan masyarakat, memajukan pendidikan dan meningkatkan kesejahteraan masyarakat [6]

Dengan demikian dari penjelasan para ahli di atas dapat disimpulkan bahwa kebijakan publik dibuat oleh pemerintah berupa tindakan-tindakan pemerintah itu sendiri, kebijakan publik sangat berorientasi pada kepentingan publik dan kebijkana publik adalah tindakan alternatif-alternatif untuk dilaksanakan atau tidak dilaksanakan oleh pemerintah demi kepentingan warga negara.

\section{Implementasi Kebijakan Publik}

Menurut Grindle mengatakan Bahwa proses implementasi kebijakan dapat dilaksanakan apabila seluruh program telah dirancang dan pembiayaan telah disediakan. [7] Selanjutnya, suatu kebijakan diambil ketika telah tersedia sumberdaya dan pembiayaan. [8] Menurut RC. Chandler dan JC Plano kebijakan publik adalah bagaiman memanfaatkan sumberdaya yang telah tersedia untuk mengatasi masalah publik. [9]

Dalam penelitian ini, teori yang menjadi acuan utama dalam pembentukan kerangka berpikir untuk memecahkan masalah adalah teori George C. Edward III. Yang mengatakan bahwa ada empat variabel yang berperan penting dalam suatu keberhasilan implementasi kebijakan yakni komunikasi, sumber daya, disposisi dan struktur birokrasi.

Selanjutnya keempat variabel tersebut akan dijelaskan lebih lanjut, sebagai berikut:

1. Komunikasi, yaitu suatu komunikasi yang dibangun oleh pemerintah sebagai pelaksana kebijakan dengan masyarakat sebagai kelompok sasaran (target Grup). Tujuannya adalah memastikan dapat tersampaikan dengan baik kepada masyarakat.

2. Sumber daya, yaitu memastikan semua kebijakan harus didukung oleh SDM yang baik, baik sumber daya manusia maupun sumber daya finansial.

3. Disposisi, yaitu memastikan ada perlakuan adil oleh implementator kepada masyarakat sebagai sasaran program. 
4. Struktur Birokrasi, yaitu memastikan mekanisme implementasi program berjalan sesuai Standar Operating Procedur (SOP) .[10]

\section{METODE}

Penelitian ini menggunakan jenis penelitian kualitatif. karena itu, peneliti adalah instrumen kunci dari penelitian itu sendiri. [11] Pendekatan penelitian ini dilakukan untuk menganalisis implementasi kebijakan pengangkatan tenaga kontrak daerah dalam upaya memperkuat desa di Kabupaten Halmahera Utara. Penelitian ini akan memfokuskan pada implementasi kebijakan pengangkatan tenaga kontrak daerah dalam upaya memperkuat desa di Kabupaten Halmahera Utara. Lokasi Pelaksanaan penelitian dilaksanakan di desa-desa sekecamatan Tobelo Tengah, untuk mengkaji 'implementasi kebijakan pengangkatan tenaga kontrak daerah dalam upaya memperkuat desa di Kabupaten Halmahera Utara'.

Dalam pemilihan key informan dilakukan dengan teknik purposive yaitu memilih orang yang mengetahui serta terlibat langsung dengan permasalahan yang sedang diteliti.[12] Dalam penelitian ini, informan penelitian terdiri dari: Bupati dan wakil Bupati Halmahera Utara, Sekretaris Daerah Halmahera Utara, Badan Kepegawaian Daerah Halmahera Utara, Anggota Dewan Perwakilan Daerah Kabupaten Halmahera Utara, Camat Tobelo Tengah, Para Kepala Desa sekecamatan Tobelo Tengah, Para Tenaga Kontrak Daerah, Tokoh Masyarakat Tobelo Tengah.

Miles dan Huberman mengemukakan bahwa analisis data yang digunakan dalam penelitian yaitu: Reduksi data, yakni data yang diperoleh dari lapangan dituangkan dalam laporan secara lengkap dan terperinci kemudian dipilih hal-hal pokok, difokuskan pada hal-hal pokok kemudian dicari polanya. Reduksi data dilakukan secara terus menerus selama proses penelitian berlangsung. Penyajian data, dimaksudkan untuk memudahkan peneliti dalam melihat gambaran secara keseluruhan atau bagian-bagian tertentu dari penelitian. Penarikan kesimpulan, melakukan verifikasi secara terus menerus sepanjang proses penelitian berlangsung. Sejak awal memasuki untuk menganalisis dan mencari makna dari data yang.[13]

\section{PEMBAHASAN}

\section{Upaya Memperkuat Desa: Suatu Implementasi Kebijakan Pengangkatan Tenaga Kontrak Daerah di Kabupaten Halmahera Utara}

Implementasi Kebijakan Edward III adalah model yang menjadi ukuran pencapaian keberhasilan kebijakan pengangkatan tenaga kontrak daerah di Kabupaten Halmahera Utara. Empat indikator tersebut adalah komunikasi, sumber daya, disposisi dan struktur birokrasi. Berdasarkan pandangan George C. Edward inilah, analisis dan pembahasan akan dilakukan yaitu dengan mengelaborasi empat poin ini untuk melihat implementasi kebijakan pengangkatan tenaga kontrak daerah di Kabupaten Halmahera Utara

\section{Komunikasi}

Komunikasi pemerintah adalah sesuatu yang sangat penting, karena pemberian informasi dapat memberikan kepercayaan publik, dimana pemerintah mendapat kesan yang baik dari publik terhadap kegiatan-kegiatan organisasi pemerintahan itu sendiri jika suatu kegiatan dikomunikasikan dengan baik. Kebijakan Pemerintah Daerah Kabupaten Halmahera Utara dalam pengangkatan tenaga kontrak daerah tidak berjalan lancer, oleh karena kurangnya komunikasi langsung kepada pemerintah desa dan ke masyarakat ini dilihat dari sebagian pemerintah desa dan masyarakat yang mengatakan tidak ada komunikasi. Kepala Desa Pitu misalnya, mengatakan kurangnya komunikasi terutama pada kerja utama dari tenaga kontrak, akibatnya para tenaga kontrak yang ditempatkan di desa yang konon katanya untuk membantu desa tidak terwujud, 3 (tiga) tenaga kontrak yang ditempatkan di desa Pitu hanya 1 (satu) yang aktif, itu pun hanya bantu-bantu sebatas rutinitas, pada hal desa membutuhkan tenaga pendampingan pembuatan laporan keuangan dan pembuatan peraturan desa (Perdes).

Selanjutnya, kepala desa WKO mengatakan program yang sangat baik jika dilihat sepintas tetapi tidak dikomunikasikan dengan baik di awal mengenai penempatan, kerja utama mereka (tenaga kontrak) sehingga ketika di desa kita susah ketemu dalam kerja-kerja pada hal jika dilihat desa sangat membutuhkan tenaga para sarjana dalam rangka percepatan pengerjaan program-program di desa. Berkaitan dengan komunikasi dalam suatu kegiatan, Louis Forsdale Mengatakan bahwa hanya melalui komunikasilah suatu sistem dapat didirikan, dipelihara dan dirubah [14] Sementara itu, Komunikasi juga mampu menghubungkan antara kepentingan masyarakat dalam menanggapi lingkungannya, lewat komunikasi interpersonal atau lewat tetua kampung, pemuka pendapat, suatu inovasi akan menjadi perbincangan hangat, kemungkinan bisa dilaksanakan atau tidak. Setelah itu jika memang baik akan 
dilaksanakan dalam jangka waktu lama dan terjadi pewarisan nilai tertentu kepada generasi selanjutnya.[15]

Dari defenisi yang dikemukakan di atas jelas, komunikasi merupakan hal yang sangat penting dalam menjalankan kegiatan ataupun program tertentu. Kebijakan pengangkatan tenaga kontrak daerah yang di tempatkan di desa-desa harusnya direncanakan dan dikomunikasikan lebih baik lagi kepada pemerintah desa, agar supaya tidak terjadi kegagalan dalam kebijakan tersebut, dimana kebijakan penmgangkatan tenaga kontrak daerah ini harus direncanakan dan dikomunikasikan dengan baik kepada pemerintah desa.

\section{Sumber Daya}

\section{a. Sumber Daya Manusia}

Keberhasilan suatu program sangat tergantung dari kemampuan memanfaatkan sumberdaya yang tersedia. Manusia merupakan sumberdaya yang terpenting dalam menentukan suatu keberhasilan program. Tahap-tahap tertentu dari keseluruhan proses implementasi menuntut adanya sumber daya manusia yang berkualitas sesuai dengan pekerjaan yang diisyaratkan oleh kebijakan yang telah ditetapkan.

Sumber daya manusia dalam implementasi kebijakan pengangkatan tenaga kontrak daerah adalah mereka yang dikontrak oleh pemerintah daerah untuk membantu desa. tenaga kontrak yang ditempatkan di desa minimal bergelar diploma dan kebanyakan sarjana, dengan demikian harapannya para tenaga kontrak bisa mampu mengerjakan tugas dengan baik. Namun, itu tenyata lain kepala Sekretaris Desa Wosia misalnya mengatakan bahwa tenaga kontrak yang ditempatkan di desa kurang mampuh mengerjakan tugas dengan baik, misalnya belum mampuh membuat laporan keuangan desa. Keluhan yang sama juga muncul dari Kepal Desa Mahia yang mengatakan bahwa sebenarnya kami sangat berharap para tenaga kontrak yang ditempatkan di desa untuk membantu kami dalam hal membuat laporan keuangan desa dan peraturan desa, tetapi para tenaga kontrak belum mampu mengerjakan pekerjaan tersebut.

Berkaitan dengan SDM, Soeroto mengemukakan, SDM merupakan potensi pembangunan melalui unsur manusia dengan segala aktivitasnya, dalam tinjauan yang bersifat ekonomis, SDM dimaksudkan sebagai semua kegiatan manusia yang produktif yang diberikan masyarakat. [16] Selanjutnya, untuk meningkatkan produktivitas tenaga kerja perlu dilakukan dengan peningkatan kemampuan/ketrampilan, disiplin, etos kerja yang baik, kreatif dan inovatif. Selanjutnya, perlu peningkatan SDM, yakni tenaga kerja dari kegiatan yang kurang produktif ke kegiatan yang lebih produktif ditingkatkan yang diikuti oleh pengembangan sistem perlindungan tenaga kerja yang baik.[17]

Dengan demikian penjelasan di atas jelas bahwa SDM Sangatlah penting dalam pelaksanaan kebijakan pengangkatan tenaga kontrak daerah karena itu harusnya pemerintah daerah lebih selektif lagi dalam hal rekrutmen dan setelah itu harus ada pendampingan-pendampingan atau pelatihan sebelum para tenaga kontrak turun di desa.

b. Sumber Daya Finansial

Selain SDM, sumber daya finansial juga perlu diperhitungkan dalam suatu kegiatan, Karena, ketika SDM yang kompeten telah tersedia dan anggaran tidak tersedia, maka memang menjadi persoalan untuk merealisasikan apa yang hendak dituju oleh tujuan program. Sumber daya finansial dalam kebijakan pengangkatan tenaga kontrak daerah adalah tersediahnya anggaran yang memadai, dalam hal ini dapat membiayai gaji para tenaga kontrak daerah. Jika dilihat dari pembiayaan program rupanya tidak ada masalah, Kepala Desa Tanjung Niara misalnya mengatakan bahwa jika dilihat dari gaji para tenaga kontrak sangatlah besar rata-rata di atas 3 jutaan dan mereka selalu terima setelah mereka menyampaikan laporan. Selanjutnya, Sekretaris Daerah Kabupaten Halmahera Utara mengatakan bahwa pemerintah daerah memberikan penghargaan cukup besar terhadap tenaga kontrak daerah, dengan harapan mereka bisa mengerjakan tugas dengan baik.

Penganggaran terhadap suatu program sangatlah penting, karena untuk mendukung terwujudnya good governance dalam penyelenggaraan pemerintahan, pengelolaan keuangan negara perlu diselenggarakan secara profesional, terbuka dan bertanggungjawab sesuai dengan aturan yang ditetapkan dalam Undang-Undang Dasar tahun 1945. [18] Selanjutnya, menurut Suparmoko bahwa pengeluaran negara adalah pengeluaran atau setiap penggunaan uang dan sumber daya suatu negara untuk membiayai program pemerintah dalam mensejahterakan rakyatnya. [19] 
Dari penjelasan di atas, jelas sumber daya finansial Sangatlah penting dalam pelaksanaan kebijakan pengangkatan tenaga kontrak daerah. Biaya yang sudah tersedia dengan baik dan lansung dirasakan oleh para tenaga kontrak harusnya para tenaga kontrak daerah bisa bekerja dengan baik.

\section{Disposisi}

Komitmen untuk senantiasa jujur dan demokratis oleh pemerintah daerah sangat diperlukan dalam pelaksanaan kebijakan pengangkatan tenaga kontrak daerah. Disposisi dalam implementasi kebijakan pengangkatan tenaga kontrak daerah yaitu apakah kebijakan tersebut sudah pada sasarannya.

Dalam pelaksanaan kebijakan pengangkatan tenaga kontrak daerah Pemerintah daerah Kabupaten Halmahera Utara terlihat telah menunjukan komitmen dalam hal kejujuran dan demokratis, dimana dalam rekrutmen dilakukan dengan terbuka dan transparan. Sekretaris Badan Kepegawaian Daerah dan Sumber daya Aparatur (BKDSDA) Halmahera Utara mengatakan bahwa proses rerutmen dilakukan secara transparan dan tertanggungjawab. Terkait dengan kejujuran, Wahyudi mengatakan, bahwa perilaku manusia sangat ditentukan oleh nilai-nilai yang dianut serta prinsip moral yang dipegangnya. Dengan demikian, moral itu sendiri merupakan suatu sistem nilai yang menjadi dasar bagi dorongan atau kecendurungan bertindak. Nilai nilai mempunyai karakteristik sebagai moral melibatkan suatu komitmen untuk bertindak dan merupakan landasan hasrat yang paling utama.[20] Sedangkan menurut Herbani Implementasi etika dan moral dalam praktek dapat dilihat dari kode etik yang dimiliki oleh administrator publik. Komitmen terhadap perbaikan etika perlu ditunjukan, agar publik mendapat kepercayaan dari pihak pemberi pelayanan sunggu-sunggu akuntabel dalam melaksanakan kegiatan pelayanan publik. Dari penjelasan di atas, nyata pentingnya komitmen dan kejujuran Pemerintah Daerah Kabupaten Halmahera Utara dalam pelaksanaan kebijakan tersebut dan itu telah dilakukan dengan model rekrutmen yang transparan dan tertanggungjawab.

\section{Struktur Birokrasi}

Struktur birokrasi yaitu mekanisme dan struktur organisasi pelaksana sendiri. Sitruktur birokrasi dalam implementasi kebijakan pengangkatan tenaga kontrak daerah adalah mekanisme pelaksanaan, dalam hal ini bagaimana kerangka kerja yang dipakai. Pelaksanaan kebijakan pengangkatan tenag kontrak daerah rupaya mendapat protes dari sesama organisasi perangkat daerah, Kepala Bidang Pemerintahan Desa DPMD Halmahera Utara misalnya mempersoalkan tata cara pekerjaan tenaga kontrak, dengan mengatakan bahwa harusnya proses rekrutmen saja yang dilakukan di BKDSDA selanjutnya diserahkan ke DPMD untuk mengelola dengan memberikan pelatihan-pelatihan agar supaya para tenaga kontrak bisa bekerja dengan baik.

Terkait dengan struktur birokrasi dalam suatu program, D. Millet mengemukakan, Organisasi merupakan kerangka struktur dimana suatu pekerjaan diselenggarakan untuk mewujudkan suatu tujuan bersama. [21] Dari penjelasan di atas, membuktikan betapa Pentingnya struktur birokrasi dalam mekanisme pelaksanaan pengangkatan tenaga kontrak daerah tentunya menunjang untuk bagaimana program tersebut dapat berjalan dengan lancar, dimana mestinya dalam pelaksanaan ada koordinasi dalam hal penempatan sampai pada pengelolaan para tenaga kontrak tersebut.

\section{KESIMPULAN DAN SARAN}

\section{Kesimpulan}

Kebijakan Pemerintah Daerah Kabupaten Halmahera Utara dalam Kebijakan pengangkatan tenaga kontrak daerah tidak berjalan lancar sesuai dengan tujuan program, oleh karena kurangnya komunikasi atau sosialisasi langsung kepada pemerintah desa atau masyarakat tentang program tersebut. Para tenaga kontrak yang ditempatkan di desa-desa sebagian besar tidak bisa melaksanakan tugas pokoknya, karena kemampuannya yang terbatas juga karena tidak diberikan tugas oleh pemerintah desa setempat. Sedangkan untuk pembiayaan program ini tidak ada masalah, semua para tenaga kontrak daerah digaji di atas standar upah minimum kabupaten (UMK).

Dalam pelaksanaan kebijakan pengangkatan tenaga kontrak daerah Pemerintah daerah Kabupaten Halmahera Utara terlihat telah menunjukan komitmen dalam hal kejujuran dan demokratis, dimana dalam rekrutmen dilakukan dengan terbuka dan transparan. Pelaksanaan kebijakan pengangkatan tenaga kontrak daerah rmendapat protes dari sesama organisasi perangkat daerah, sebagaimana yang disampaikan oleh Kepala Bidang Pemerintahan Desa DPMD Halmahera Utara bahwa proses rekrutmen saja yang dilakukan di 
Badan Kepegawaian Daerah dan Sumber Daya Aparatur (BKDSDA) selanjutnya diserahkan ke DPMD untuk mengelola dengan memberikan pelatihan-pelatihan.

\section{Saran}

Niat baik pemerintah daerah untuk memperkuat desa, harusnya direncanakan dengan baik dan selanjutnya disosialisaikan kepada pemerintah desa atau masyarakat terlebih dahulu tentang tujuan program sehingga tidak ada penolakan oleh pemerintah desa. Proses rekrutmen harusnya memilih para tenaga kontrak yang sesuai besik ilmu dan mampu melakukan pekerjaan yang diberikan. Selain itu, setelah proses rekrutmen, selanjutnya BKDSA bekerjasama DPMD untuk melakukan pembinaan dan pelatihan-pelatihan mengenai tugas dan kerja tenaga kontrak daerah.

\section{DAFTAR PUSTAKA}

Undang-Undang Nomor 6 Tahun 2014 Tentang Desa.

Keputusan Bupati Halmahera Utara bernomor 814.1/2018 Tentang Pengangkatan Tenaga Kontrak Daerah dengan Perjanjian Kerja di Desa Dalam Wilayah Kabupaten Halmahera Utara.

Winarno, Budi, 2014, Kebijakan Publik Teori, Proses dan Studi Kasus. Yogyakarta: Center Of Akademic Publishing Service.

Subarsono AG. 2008. Analisis Kebijakan Publik Konsep Teori dan aplikasi. Yogyakarta. Pustaka Pelajar.

Mulyadi Deddy. 2015. Studi Kebijakan Publik dan Pelayanan Publik; Konsep dan Aplikasi Proses Kebijakan Publik dan Pelayanan Publik. Bandung. Alfabeta.

Pasolong. Herbani. 2007. Teori Administrasi Publik. Bandung: Alfabeta.

Wahab Abdul Solichin. 2008. Pengantar Analisis Kebijakan Publik. Malang. UMM Pres.

Keban T. Yeremias. 2008. Enam Dimensi Strategis Administrasi Publik Konsep Teori Dan Isu. Yogyakarta . Gava Media.

Syafiie, Kencana, Inu. 2010, Sistem Administrasi Negara Republik Indonesia, Bumi Aksara, Jakarta

Indiahono, Dwiyanto, 2009. Kebijakan publik Berbasis Dinamic Policy Analisys, Yogyakarta: Gava Media

Moleong, Lexi J, 2006, Metode Penelitian Kualitatif, Bandung, Remaja Rosdakarya.

Sugiono, 2015, Metode Penelitian Kualitatif dan R\&D, Bandung. Alfabeta,

Ghony, 2012, Metode Penelitian Kualitatif,, Yogyakarta, Ar-Ruzz Media

Arni Muhammad, 2002, Komunikasi Organisasi, Bumi Aksara, Jakarta.

Nurudin, 2008, Sistem Komunikasi Indonesia, RajaGrafindo Persada, Jakarta

Soetomo, 2009, Pembangunan Masyarakat, Pustaka Pelajar, Yogyakarta

Mulyadi S, 2008, Ekonomi Sumber Daya Manusia Dalam Perspektif Pembangunan, RajaGrafindo Persada, Jakarta.

Sumarsono, Sonny. 2010, Manajemen Keuangan Pemerintahan, Graha Ilmu, Yogyakarta.

Suparmoko, 2000, Keuangan Negara, BPFE, Yogyakarta.

Kumorotomo, Wahyudi, 2008, Etika Administrasi Negara, RajaGrafindo Persada, Jakarta.

Syafiie, Kencana, Inu, 2006. Ilmu Administrasi Publik, Jakarta : Rineka Cipta. 